\title{
PENERAPAN BAHASA INGGRIS DENGAN MENGGUNAKAN METODE STORY TELLING UNTUK ANAK USIA DINI
}

\author{
Yuspar Uzer, M.Pd
}

\author{
Univ. PGRI Palembang \\ Email: yusparu@gmail.com
}

\begin{abstract}
Abstrak :Pembelajaran Bahasa Inggris untuk anak usia dini (English for Young Learners) sangat dibutuhkan dalam perkembangan kemampuan siswa khususnya PAUD. Kemampuan seseorang dalam menggunakan bahasa Inggris sangatlah dibutuhkan seiring dengan kemajuan sebuah negara. Karenanya pendidikan bahasa Inggris sebagai bahasa Internasional mulai diperkenalkan sedini mungkin kepada anak didik di Indonesia saat ini. Pendidikan bahasa Inggris akan sangat ideal jika dimulai sejak usia dini, terutama sebelum mereka menginjak umur 12 tahun. Anak usia dini adalah anak pada rentang usia 2 - 7 tahun. Pada rentang usia tersebut merupakan periode emas perkembangan kemampuan berbahasa anak. Mereka mampu belajar bahasa apapun seperti penutur aslinya dan periode ini harus dimanfaatkan sebaikbaiknya. Akan tetapi, anak-anak pada usia dini masih pada kondisi perkembangan kognitif praoperasional yaitu memiliki egosentris yang tinggi, belum mengerti hal-hal abstrak, hanya mengerti pada simbol-simbol dan masih berpikiran pra-logis. Oleh sebab itu, EYL membutuhkan metode dan proses pengajaran yang tepat dan efektif. Ada beberapa metode dan teknik yang sesuai untuk pengajaran bahasa Inggris bagi anak usia dini antara lain dalam konteks yang komunikatif meliputi konteks situasi sosial, kultural, permainan, nyanyian dan musik, pembacaan cerita, pengalaman-pengalaman kesenian, kerajinan tangan dan mengutamakan gerakan fisik. Dan diantara metode dan teknik tersebut maka pendekatan dengan metode story telling adalah metode yang sangat sesuai dan berhasil dalam pendidikan bahasa Inggris untuk anak usia dini pada TK Rose Palembang.
\end{abstract}

Key words: bahasa Inggris, story telling, pendidikan bahasa Inggris untuk anak usia dini

\section{PENDAHULUAN}

Pendidikan anak usia dini merupakan peletak dasar pertama dan utama dalam pengembangan pribadi anak, baik berkaitan dengan karakter, kemampuan fisik, kognitif, bahasa, seni, sosial emosional, spiritual, disiplin diri, konsep diri, maupun kemandirian. Pendidikan anak usia dini memegang peranan penting dan menentukan bagi sejarah perkembangan anak selanjutnya karena merupakan pondasi bagi dasar kepribadian anak.

Era globalisasi menuntut kita untuk menguasai bahasa Inggris baik secara lisan dan tulisan. Tuntutan tersebut membuat para orang tua berlomba-lomba memasukkan anak mereka ke sekolah yang bertaraf internasional ataupun nasional plus dimana media bahasa yang digunakan adalah bahasa Inggris. Tak perduli akan kemampuan psikologi bahasa anak, usia anak, pendidikan para pendidik serta metode yang diajarkan, yang penting jika ada lisensi internasional dan berbahasa Inggris maka para orang tua akan puas dan percaya pada pendidikan tersebut. Akibatnya, banyak anak yang frustasi dan stress. Alih-alih bukannya penguasaan bahasa Inggris yang mereka dapatkan, malah menjadi anak karbitan yang terpaksa berbahasa Inggris. Sehingga pelafalan bunyi dan struktur kalimat bahasa yang mereka ucapkan banyak yang salah dan nyeleneh. Sebenarnya, perlu adanya pertimbangan bagi para orang tua 
untuk memasukkan anak mereka pada pendidikan yang bermedia bahasa Inggris. Usia anak merupakan pertimbangan yang penting dalam pembelajaran bahasa Inggris (bahasa asing). Pada usia berapakah seorang anak seharusnya memperoleh pembelajaran bahasa asing (bahasa Inggris)? Dan metode dan proses pengajaran yang bagaimanakah yang sesuai dan tepat untuk anak usia dini? Masalah ini menjadi pertimbangan penulis untuk membahas dan menjabarkannya dalam jurnal tulisan ini.

Pendidikan bahasa asing untuk anak-anak di Amerika dan Eropa sudah dimulai sejak tahun lima puluhan dan menjadi sangat populer pada tahun enam puluhan, namun agak menurun pada tahun tujuh puluhan. Pendidikan dan pembelajaran bahasa Inggris didasari suatu pemikiran bahwa belajar bahasa asing atau bahasa kedua akan lebih baik bila dimulai lebih awal (Hammerby, 1982 : 265). Banyak asumsi tentang usia dan pembelajaran bahasa antara lain adalah anak-anak belajar bahasa lebih baik dari pebelajar dewasa, pembelajaran bahasa asing disekolah sebaiknya dimulai seawal mungkin, lebih mudah menarik perhatian dan minat anak-anak daripada orang dewasa seperti diungkapkan oleh Ur (1996 : 296). Asumsi tersebut belum dikomfirmasi dengan penelitian walaupun dari pengalaman kelihatannya pebelajar anak-anak lebih baik dan ternyata ada bukti bahwa lebih tua usia anak lebih efektif dia belajar bahasa (Ur ; 1996). Pada pendidikan taman kanak-kanak sudah menjadi karakeristik bahwa dalam pembelajaran harus lebih beragam menggunakan metode atau sumber belajar dengan alat bantu dimana anak yang sulit memahami abstrak harus dimulai dari konkrit, mengenalkan dari hal yang sederhana menuju kompleks hal yang mudah baru ke hal yang lebih sulit dan seterusnya, penggunaan sumber belajar dan alat bantu yang beragam akan membuat pembelajaran menajdai menarik dan menyenangkan, mempermudah dan mempercepat pemahaman anak memepertahankan konsentrasi anak lebih lama serta menghambat kejenuhan dalam belajar.

Berdasarkan pendapat diatas maka peneliti tertarik untuk melakukan penelitian dengan menggunakan metode storytelling berbantu media cerita bergambar dalam mengenalkan bahasa inggris, karena metode ini dianggap akan menjadi salah satu metode yang disukai anak-anak sehingga anak dapat belajar mendapatkan bahasa asing yang sederhana dengan keadaan yang gembira dan tetap konsentrasi.

Metode Storytelling merupakan salah satu kegiatan yang dilaksanakan dalam Taman kanak-kanak dengan tujuan 
dapat mengembangkan aspek bahasa khususnya bahasa inggris pada anak, penulis berangapan bahwa judul tersebut nantinya akan bermanfaat untuk penulis selanjutnya menerapkan metode ini menjadi guru anak usia dini.

\section{PEMBAHASAN}

\section{Bahasa Inggris}

Bahasa Inggris telah menjadi bahasa Internasional yang digunakan hampir di segala bidang kehidupan global. Bahasa Inggris juga telah menjadi bahasa dunia yang mendominasi era komunikasi untuk menghubungkan dan mentransfer ilmu ke seluruh dunia. Hal ini memberikan asumsi bahwa penguasaan bahasa Inggris merupakan kebutuhan yang sangat penting bagi masyarakat modern sekarang ini karena penguasaan terhadap bahasa Inggris memudahkan seseorang untuk memperluas pergaulannya di dunia internasional. Seperti yang dikatakan oleh Fromkin, "English has been called 'the lingua franca of the world"' (1990: 259).

Kedudukan Bahasa Inggris di Indonesia merupakan bahasa asing pertama (the first foreign language). Kedudukan tersebut berbeda dengan bahasa kedua. Mustafa (2007) dalam hal ini menyatakan bahwa bahasa kedua adalah bahasa yang dipelajari anak setelah bahasa ibunya dengan ciri bahasa tersebut digunakan dalam lingkungan masyarakat sekitar. Sedangkan bahasa asing adalah bahasa negara lain yang tidak digunakan secara umum dalam interaksi sosial. Kedudukan bahasa Inggris di Indonesia tersebut mengakibatkan jarang digunakannya bahasa Inggris dalam interaksi sosial di lingkungan masyarakat sehingga bahasa Inggris merupakan bahasa yang sulit untuk dipelajari karena bahasa Inggris merupakan bahasa asing yang tidak digunakan sehariharidalam kehidupan masyarakat di Indonesia.

Faktanya, penguasaan bahasa Inggris adalah keterampilan yang sangat penting dalam era informasi dan komunikasi saat ini. Hal ini sangat menentukan bagaimana kita dapat berinteraksi secara global. Isu globalisasi saat ini menuntut sumberdaya manusia yang berkualitas dan mampu berkomunikasi dalam berbagai bahasa asing terutama bahasa Inggris sebagai bahasa internasional. Keahlian berbahasa asing ini diperlukan untuk menguasai ilmu pengetahuan, memiliki pergaulan luas dan karir yang baik. Hal ini membuat semua orang dari berbagai kalangan termotivasi untuk mengusai bahasa Inggris.

Kecenderungan masyarakat akan penguasaan bahasa asing tersebut, membuat mereka saling berlomba memasukkan anak-anak mereka untuk mempelajari bahasa Inggris sebagai salah satu keahlian yang dikembangkan. Hal ini berdasarkan asumsi bahwa anak lebih 
cepat belajar bahasa asing dari pada orang dewasa (Santrock, 2007:313). Sebuah penelitian yang dilakukan Johnson dan Newport, 1991 (Santrock, 2007:313) menunjukan bahwa imigran asal Cina dan Korea yang mulai tinggal di Amerika pada usia 3 sampai 7 tahun kemampuan bahasa Inggrisnya lebih baik dari pada anak yang lebih tua atau orang dewasa. Penelitian lain yang menyatakan kebermanfaatan menguasai bahasa asing lebih dini, dinyatakan Mustafa (2007), bahwa anak yang menguasai bahasa asing memiliki kelebihan dalam hal intelektual yang fleksibel, keterampilan akademik, berbahasa dan sosial. Selain itu, anak akan memiliki kesiapan memasuki suatu konteks pergaulan dengan berbagai bahasa dan budaya. Sehingga ketika dewasa anak akan menjadi sumber daya manusia yang berkualitas dan bisa berprestasi. Mustafa (2007) menambahkan bahwa pemahaman dan apresiasi anak terhadap bahasa dan budayanya sendiri juga akan berkembang jika anak mempelajari bahasa asing sejak dini. Alasannya karena mereka akan memiliki akses yang lebih besar terhadap bahasa dan budaya asing.

Akan tetapi, pengajaran bahasa Inggris di Indonesia berbeda dengan pengajaran bahasa Inggris sebagai bahasa kedua di negara di mana bahasa Inggris sebagai media komunikasi. Di Indonesia, posisi bahasa Inggris merupakan bahasa asing pertama yang wajib diajarkan di SLTP dan SMU sedangkan di SD merupakan salah satu pelajaran muatan lokal yang sebenarnya bukan (atau) belum merupakan mata pelajaran wajib. Meskipun pada saat ini bahasa Inggris telah dicoba menjadi bahasa asing sebagai matapelajaran atau nantinya sebagai "medium" dalam bilingual education (Chamot, 1987). Bahkan, saat ini sedang dicoba program pembelajaran bilingual untuk mata pelajaran matematika dan IPA di Sekolah Dasar kelas 4 dan 5 (42 SD di 30 propinsi).

Sebenarnya, tujuan pengajaran bahasa Inggris mencakup semua kompetensi bahasa, yaitu menyimak (listening), berbicara (speaking), membaca (reading), dan menulis (writing). Bahasa Inggris juga sangat berbeda dengan bahasa pertama anakanak (bahasa Indonesia, Jawa, Sunda, dan bahasa daerah yang lain di Indonesia). Perbedaan kebahasaan ini penting untuk dipahami agar pembelajaran dapat dipertanggungjawabkan kebenarannya. Perbedaan tersebut antara lain: ucapan, ejaan, struktur bahasa, tekanan dan intonasi, kosakata, dan nilai kultur bahasa asing. Bahasa Inggris juga diketahui sebagai bahasa yang cermat waktu (tenses), cermat angka (singularplural), dan cermat orang (feminine dan maskulin). 


\section{Metode Story Telling}

Menurut Echhols (dalam aliyah) Storytelling terdari atas dua kata yaitu story berarti bercerita dan telling berarti penceritaan. Penggabungan dua kata storytelling berarti penceritaan cerita atau menceritakkan cerita. Selain itu Storytelling disebut juga bercerita atau mendongeng seperti yang dikemukakan oleh Nalan, bercerita adalah mendongeng berdasarkan cerita lisan. Storytelling merupakan usaha yang dilakukan oleh pendongeng dalam menyampaikan isi perasaan, buah pikiran atau sebuah cerita kepada anakanak. Sedangkan, metode merupakan upaya untuk mengimplementasikan rencana yang sudah disusun dalam kegiatannya atau agar tujuan yang telah disusun tercapai secara optimal.25 Metode digunakan untuk merealisasikan strategi yang telah ditetapkan. Strategi menunjuk pada sebuah perencanaan untuk mencapai sesuatu, sedangkan metode adalah cara yang dapat digunakan untuk melaksanakan strategi. Metode Storytelling menurut Brewster \& Ellis, mengatakan bahwa menyampaikan penyampaian peristiwa ini dapat menceritakan kisah dari

buku dengan membacanya atau tanpa buku secara lisan. Cerita yang disampaikan bisa berupa lelucon atau pengalaman seharihari. Pelaksanaan pembelajaran anak usia dini melalui kegiatan bercerita diharapkan anak dapat menyerap pesan yang disampaikan melalui cerita. Sedangkan menurut Lilis Madyawati berpendapat bahwa metode Storytelling merupakan penceritaan cerita yang dilakukan secara terencana dengan menggunakan boneka, atau benda-benda visual, metode ini bertujuan untuk menghasilkan kemam puan berbahasa anak. Penggunaan metode ini dibutuhkan untuk melatih dan membentuk ketrampilan berbicara, pengembangkan daya nalar, dan pengembanangkan imajinasi anak. Metode ini contohnya seperti metode sandiwara boneka, metode bermain peran, metode bercakap-cakap dan metode tanya jawab. Cameron mengatakan bahwa Storytelling adalah merupakan kegiatan lisan yang dirancang bukan hanya untuk didengrkan tetapi juga untuk terlibat didalamnya. Cameron percaya bahwa kosakata dalam cerita ditampilkan melalui konteks yang jelas dibantu oleh pola peristiwa ,bahasa dan gambar yang mudah diduga akan menambah kosa kata pada anak, selain itu kejelasan makna suatu kosakata dapat berbentuk dengan adanya penggunaan mimik gerak dan bahasa tubuh yang di peragakan guru.

\section{Pendidikan Bahasa Inggris untuk Anak Usia Dini}

Periode paling sensitif terhadap bahasa dalam kehidupan seseorang adalah antara umur dua sampai tujuh tahun. 
Segala macam aspek dalam berbahasa harus diperkenalkan kepada anak sebelum masa sensitif ini berakhir. Pada periode sensitif ini sangat penting diperkenalkan cara berbahasa yang baik dan benar, karena keahlian ini sangat berguna untuk berkomunikasi dengan lingkungannya (Maria Montessori,1991). Berdasarkan teori tersebut, adalah tepat jika bahasa Inggris mulai diperkenalkan kepada anak sedini mungkin. Mengingat bahasa Inggris merupakan bahasa asing pertama di Indonesia, maka proses pembelajarannya harus dilakukan secara bertahap. Pemilihan materi yang sesuai dengan usia anak dan juga efektif untuk perkembangan kognitif bahasa anak serta situasi belajar yang menyenangkan haruslah menjadi perhatian utama dalam berhasilnya suatu proses pembelajaran. Keberhasilan proses pembelajaran bahasa Inggris pada anak usia dini tentunya dipengaruhi oleh banyak faktor, antara lain :

1. Guru yang berkualitas, guru yang dapat menghidupkan proses kegiatan belajar mengajar.

2. Sumber dan fasilitas pembelajaran yang memadai dan memenuhi syarat (adekuat).

3. Kurikulum yang baik, sederhana, dan menarik (atraktif).

Di sisi lain perlu dipahami bahwa usia dini adalah usia bermain. Setiap anak adalah pribadi yang unik dan dunia bermain merupakan kegiatan yang serius namun mengasyikan bagi mereka. Maka pendekatan yang tepat perlu diciptakan oleh seorang pendidik agar proses pembelajaran bahasa Inggris lebih menarik dan menyenangkan tanpa meninggalkan kaidah-kaidah bahasa yang benar.

Pendekatan yang digunakan hendaknya sejalan dengan tujuan pengenalan bahasa pada umumnya. Tujuan tersebut ialah supaya anak dapat memahami cara berbahasa yang baik dan benar, berani mengungkapkan ide atau pendapatnya dan dapat berkomunikasi dengan lingkungannya. Dalam pembelajaran bahasa Inggris banyak metode dan teknik yang dapat digunakan, diantaranya melalui:

a. Story Telling (Bercerita)

b. Role Play (Bermain Peran)

c. Art and Crafts (Seni dan Kerajinan Tangan)

d. Games (Permainan),

e. Show and Tell,

f. Music and Movement (Gerak dan Lagu) dimana termasuk di dalamnya

- Singing (Nyanyian)

- Chants and Rhymes (Nyanyian Pendek dan Sajak), dan sebagainya.

Metode dan teknik yang hendak digunakan sebaiknya dipilih dan disesuaikan dengan kemampuan yang ingin dicapai. Profesionalisme seorang pendidik di dalam mengembangkan dan memanfaatkan metode dan teknik tersebut sangatlah 
dibutuhkan agar proses belajar mengajar dapat berjalan lebih baik. Metode dan proses pengajaran dalam konteks yang komunikatif meliputi konteks situasi sosial, kultural, permainan, nyanyian dan musik, pembacaan cerita, pengalamanpengalaman kesenian, kerajinan dan mengutamakan gerakan fisik adalah metode yang sangat sesuai dan efektif jika digunakan dalam proses belajar bahasa Inggris khususnya bagi anak usia dini. Selanjutnya, menurut Matondang (2005 : 134) musik dan gerak adalah metode ang sangat berhasil jika digunakan dalam proses belajar bahasa Inggris khususnya bagi anak usia dini. Karena pada hakekatnya music (lagu nyanyian) adalah seni menyusun nada atau suara dalam urutan, kombinasi, dan hubungan temporal untuk menghasilkan komposisi yang mempunyai kesatuan dan kesinambungan (mengandung irama). Dan ragam nada atau suara yang berirama disebut juga dengan lagu. Jadi musik ataupun lagu merupakan satu kesatuan yang tidak dapat dipisahkan dan dapat digunakan sebagai sarana dalam sebuah proses pembelajaran.

Storytelling memiliki banyak tujuan. Tak hanya bagi anak-anak tetapi juga bagi orang yang mendongengkannya. Menurut Hibana tujuan dari kegiatan Storytelling sebagai berikut:

1.Mengembangkan fantasi, empati dan berbagai jenis perasaan lain
2. Menumbuhkan minat baca

3.Membangun kedekatan dan keharmonisan

4. Media pembelajaran.

\section{HASIL}

Pendidikan merupakan upaya manusia dewasa membimbing kepada yang belum dewasa. Sedangkan Pendidikan anak usia dini (PAUD) adalah jenjang pendidikan sebelum jenjang pendidikan dasar yang merupakan suatu upaya pembinaan yang ditujukan bagi anak sejak lahir sampai dengan usia enam tahun yang dilakukan melalui pemberian rangsangan pendidikan untuk membantu pertumbuhan dan perkembangan jasmani dan rohani agar anak memiliki kesiapan dalam memasuki pendidikan lebih lanjut. TK adalah salah satu bentuk satuan pendidikan anak usia dini pada jalur formal yang menyelenggarakan program pendidikan bagi anak usia empat sampai enam tahun. Bromely menyatakan bahwa bahasa memilki dua simbol, Simbol visual yaitu dapat dilihat, ditulis, dan dibaca, sedangkan simbol verbal dapat diucapkan dan didengar. Anak dapat memanipulasi simbol-simbol tersebut dengan berbagai cara sesuai dengan kemampuan berpikirnya, begitupun pembelajaran diusia pra sekolah dalam mengenalkan sebuah bahasa atau kalimat perlu adanya bahasa non verbal yaitu simbol visual yang akan membantu daya ingat anak karena 
melihat langsung benda yang disebutkan.

Sedangkan menurut Susanto, Pembelajaran bahasa pada anak diawali dengan kegiatan mendengar kosa kata atau kalimat yang diujarkan orang lain, memahaminya, kemudian akhirnya merespon.

Dalam kegiatan metode storytelling dapat diperolah bahasa baru bahasa selain bahasa ibu. Misalnya: bahasa pertama bahasa Indonesia dan bahasa kedua adalah bahasa Inggris, sehingga dapat mengembangkan aspek bahasa melalui pembelajaran yang terintegrasi dengan aspek perkembangan lainnya hal tersebut diperkuat dengan pendapat A Faidal Bahasa Inggris sebagai bahasa Internasional memiliki peranan yang sangat penting dalam kehidupan kita karena bahasa tersebut telah menjadi suatu kewajiban untuk dipelajari berbagai lapisan masyarakat.

Pembelajaran bahasa asing atau bahsa inggris apada anak pra sekolah adalah masa yang tepat untuk diperkenalkan karena anak usia dini akan lebih mudah dalam menyerap bahasa baru sesuai dengan pandapat Hurlock yang menyatakan bahwa masa awal masa kanak-kanak adalah saat yang tepat untuk memulai mempelajari bahasa asing, karena keluwesan anak meniru bunyi sebagai akibat kekenyalan mekanisme suara dan belum ada kebiasaan kebiasaan pengucapan yang sudah matang.oleh karena itu pada penelitian ini pengenalan bahasa ingris anak melalui metode storytelling berbantu media cerita bergambar

\section{KESIMPULAN}

Pada hasil tindakan siklus I dan II metode storytelling berbantu media cerita bergambar terbukti efektif untuk meningkatkan pengenalan bahasa Inggris pada anak kelompok B TK Rose Palembang. Metode storytelling berbantu media cerita bergambar ini belum pernah diberikan kepada anak di TK Rose Palembang dalam kegiatan bercerita yang membuat anak senang serta antusias untuk untuk mengenal bahasa Inggris yang anak ketahui, selain untuk mengembangakan bahasa anak metode ini juga dapat digunakan untuk meningkatkan daya konsentrasi anak, meningkatkan interaksi anak dengan teman, interaksi anak dengan guru. sehingga dapat dsimpulkan bahwa motode storytelling berbantu media cerita bergambar berhasil digunakan untuk meningkatkan pengenalan bahasa Inggris pada anak pada TK Rose Palembang.

\section{DAFTAR PUSTAKA}

Brumfit, Christopher; Jayne Moon \& Ray Tongue (eds.).(1991). Teaching English to Children : From Practice to Principle. London : Harper Collins Publishers

Cameron, Lynne. (2001). Teaching Language to Young Learners. 
Cambridge :Cambridge University

Press.

Chamot, Anna Uhl. (1987). Toward a

Functional ESL Curriculum in the Elementary School, in Long, Michael H. \& Richards, Jack C. (eds.) Methodology in TESOL.New York : Newburry House Publishers.

Curtain, Helena and Pesola, Carol A.B. (1994). Language and Children. New York :Longman Publishing Group. Dahar, Ratna Willis. Prof. Dr. (1988). Teori-Teori Belajar. Jakarta: P2LPTK.

Donaldson, Orlich. (1998). Teaching Strategies. Boston : Houghton Miffin Company.

Departemen Pendidikan dan Kebudayaan. (1994). Petunjuk teknis proses belajar mengajar di taman kanak-kanak, Depdikbud.

Hammerly, Hector (1982). Synthesis in Second Language Teaching. Blane : Second Language.

Matondang, Elizabeth Marsaulina (2005). Menumbuhkan Minat Belajar Bahasa Inggris Anak Usia Dini melalui Lagu dan Gerak. Jakarta : Jurnal Pendidikan Penabur.

Montessori, Dr. Maria. (1991). The discovery of the Child. New York: Ballatine Books

Mustafa, Bacharudin (2007) Buku Pendidikan Anak Usia Dini, unpublish.

Paul Suparno. Prof. (2003). Teori Perkembangan Kognitif Jean Piaget. Yogyakarta: Kanisius.

Setyiarini, Sri. Pengembangan Model Pembelajaran Berbasis Srtorytelling: Sebuah Terobosan Dalam Upaya Meningkatkan Output Pemebelajaran Bahasa Unggris Anak Usia Dini, Journal penelitian Pendidikan, 15.2 tahun 2016 